DOI : 10.29408/jit.v4i1.2995 Link : https://dx.doi.org/10.29408/jit.v4i1.2995

\title{
Pendataan Mitra Produk Herbal CV. Rinjani Tirta Lombok Timur Berbasis Geographic Information System (GIS)
}

\author{
Imam Fathurrahman ${ }^{1 *}$, L M Samsu² \\ 1 Program Studi Teknik Informatika, Universitas Hamzanwadi \\ 2 Program Studi Sistem Informasi, Universitas Hamzanwadi \\ *kulq85@gmail.com
}

\begin{abstract}
Abstrak
Tujuan dari penelitian ini adalah memudahkan konsumen dalam mencari mitra yang menjual produk herbal dari CV. Rinjani Tirta yang berada di Lombok timur. Dimana perusahaan tersebut bergerak di bidang produk herbal dan memiliki 86 lebih produk, bahkan merupakan salah satu perusahaan yang mendapat izin BPOM di lombok timur serta direkomendasikan oleh BPOM untuk tetap mengikuti kegiatan diadakan oleh BPOM maupun pemerintah berkaitan dengan izin, seminar, dan pameran produk. Penggunaan Geographic information system (GIS) dapat membantu memberikan informasi pendataan mitra yang berkerja sama dengan perusahaan. Penulis melakukan penelitian dengan beberapa tahap yaitu pengumpulan informasi, perencanaan, pengembangan format produk awal, uji coba produk awal, uji coba lapangan, revisi produk dan hasil akhir. Lokasi penelitian yaitu perusahaan CV.Rinjani Tirta yang berada di desa Ajani Timur kecamatan suralaga. Hasil dari penelitian ini yaitu sangat membantu CV.Rinjani Tirta dalam promosi serta pengumpulan informasi mengenai mitra dan daerah yang sudah banyak tersebar dan memudahkan konsumen dalam mencari produk herbal. Selain itu, untuk mengefektifkan kerja dari karyawan dan tentunya promosi dari mitra secara tidak langsung.
\end{abstract}

Kata Kunci : Pendataan mitra, Sistem Informasi Geografis (SIG), Produk Herbal, CV. Rinjani Tirta

\begin{abstract}
The purpose of this research is to facilitate consumers in finding partners who sell herbal products from CV. Rinjani Tirta which is in East Lombok. Where the company is engaged in herbal products and has more than 86 products. In fact, it is one of the companies that has obtained a BPOM permit in East Lombok and has been recommended by the BPOM to continue to participate in activities held by the BPOM and the government related to permits, seminars, and product exhibitions The use of a Geographic Information System (GIS) can help provide information on the data collection of partners working with companies. The author researched with several stages, namely information gathering, planning, development of initial product formats, initial product trials, field trials, product revisions, and final results. The location of the research is CV. Rinjani Tirta located in the village of Ajani Timur, Suralaga subdistrict. The results of this study are very helpful CV. Rinjani Tirta in promotion and gathering information about partners and areas that have been widely spread and make it easier for consumers to find herbal products. Besides, to streamline the work of employees and of course indirect promotions from partners.
\end{abstract}

Keywords :Data collection partners, Geographic Information System (GIS), Herbal Products, CV. Rinjani Tirta.

\section{Pendahuluan}

Perkembangan teknologi sekarang semakin cepat ,hal ini mendorong perusahaan atau instansi pemerintah untuk melakukan kegiatan secara efesien dan efektif agar tidak ketinggalan. Berbasis online merupakan salah 
DOI : 10.29408/jit.v4i1.2995 Link : https://dx.doi.org/10.29408/jit.v4i1.2995

satu cara yang dapat diterapkan dan dimanfaatkan[1]. Sebagai contoh aplikasi berbasis android sebagai sistem informasi desa dalam memudahkan pelayanan masyarakat karena dapat di akses dimanapun[2]. Adapun aplikasi berbasis Geographic information system (GIS) seperti pemetaan rumah makan yang berada di Lombok timur yang membantu masyarakat untuk mengetahui letak rumah makan yang ada[3], atau pemetaan bengkel tambal ban yang membantu masyarakat ketika berkendaraan mengalami ban boncor sehingga memudahkan mencari tempat tambal ban terdekat[4]. Bahkan GIS dimanfaatkan untuk pemetaan bencana longsor, pemetaan lokasi perkebunan, pemetaan daerah rawan banjir, dan lain lain yang dapat dengan mudah di akses melaui web oleh masyarakat[5]-[8]

Selain dalam pemetaan lokasi, penggunaan GIS dapat membantu informasi pendataan mitra yang berkerja sama dengan perusahaan, khususnya dalam penelitian ini yaitu CV . Rinjani Tirta yang berada di Lombok timur bergerak di bidang produk herbal dan memiliki 86 lebih produk. Tujuan dari penelitian ini adalah memudahkan konsumen dalam mencari mitra yang menjual produk herbal dari $\mathrm{CV}$. Rinjani Tirta. Dari permasalahan yang telah dijelaskan di atas maka dibutuhkan sebuah system informasi geografis untuk mengetahui siapa saja mitra dari CV. Rinjani Tirta dengan harapan mempermudah konsumen dalam mencari dan membeli produk herbal.

\section{Tinjauan Pustaka}

\subsection{Penelitian Terkait}

"Pemetaan Rumah Makan Lesehan Di Kecamatan Selong Dan Masbagik Kabupaten Lombok Timur Berbasis Gis (Geographic Information System)". Penelitian yang dilakukan Amri muliawan Nur bertujuan untuk menghasilkan sistem informasi geografis dengan visualisasi yang berisi letak rumah makan lesehan di kecamatan selong dan masbagik, informasi rumah makan berisi petunjuk dan arah menuju rumah makan lesehan. Adapun data yang digunakan dalam penelitian ini adalah dengan mengumpulkan data peta wilayah kecamatan selong dan masbagik menggunakan Google Map API dan Google Map Direction Service, pengumpulan data titik koordinat serta beberapa data penunjang lainnya[3].

"Penerapan Sistem Informasi Geografis Untuk Pemetaan Bengkel Tambal Ban di Kecamatan Selong". Menurut Aris sudianto dalam penelitiannya memudahkan mayarakat untuk mengetahui semua lokasi sebaran bengkel Tambal ban yang tersebar di kecamatan selong, sehingga saat berada di mana saja asalkan memasuki wilayah selong, masyarakat tidak perlu khawatir jika motor atau mobil mengalami 
DOI : 10.29408/jit.v4i1.2995 Link : https://dx.doi.org/10.29408/jit.v4i1.2995

pecah ban, dikarenakan lokasi sebaran bengkel tambal ban sudah dapat diakses dari mana saja asalkan terkoneksi dengan internet[4].

"Perancangan Sistem Pengelolaan Penanggulangan Bencana Alam Garut Berbasis Sistem Informasi Geografis" dalam penelitian Rubi setiawan dapat memberikan informasi daerah rawan bencana banjir dan dilengkapi fasilitas kelola data peta, sehingga jika terjadi kesalahan data, pengembang tidak perlu membuat ulang petanya[5].

Menurut Musli yanto dalam penelitian "Sistem Informasi Geografis Lokasi Perkebunan Disepanjang Garis Pantai Pesisir Selatan Berbasis Android" aplikasi Android memberikan informasi kepada para pengguna sistem, sehingga nantinya dapat bermanfaat untuk membantu dalam pencarian informasi mengenai perkebunan disepanjang garis pantai Pesisir Selatan[6].

Penelitian yang dilakukan Aris sudianto dengan judul "Penerapan Sistem Informasi Geografis (GIS) dalam Pemetaan Kerajinan Kain Tenun dan Gerabah untuk Meningkatkan Potensi Kerajinan di Kabupaten Lombok Timur" memanfaatkan GIS untuk mengetahui detail lokasi dan informasi secara cepat dan akurat, selain itu juga, bertujuan untuk mengatasi masalah yang dihadapi para pegerajin khususnya dalam hal pemasaran serta melestarikan kerajinan Kain Tenun dan Gerabah[8].

\subsection{Landasan Teori}

1. Pendataan

Pemetaan adalah pengelompokkan suatu kumpulan wilayah yang berkaitan dengan beberapa letak geografis wilayah yang meliputi dataran tinggi, pegunungan, sumber daya dan potensi penduduk yang berpengaruh terhadap sosial kultural yang memilki ciri khas khusus dalam penggunaan skala yang tepat. [9].

Pengertian lain tentang pemetaan yaitu sebuah tahapan yang harus dilakukan dalam pembuatan peta. Langkah awal yang dilakukan dalam pembuatan data, dilanjutkan dengan pengolahan data, dan penyajian dalam bentuk peta [10].

Pendataan juga diartikan dengan proses dalam mengumpulkan beberapa data, proses pengumpulan tersebut yang disebut pendataan. Pendataan juga sebuah homonim karena artinya memiliki ejaan dan pelafalan yang sama tetapi maknanya berbeda. Pendataan memiliki arti dalam kelas nomina atau kata benda sehingga pendataan dapat menyatakan nama dari seseorang, tempat, atau semua benda dan segala yang dibendakan.

2. Mitra

Mitra adalah teman, partner, sahabat atau hubungan dua belah pihak yang saling 
DOI : 10.29408/jit.v4i1.2995 Link : https://dx.doi.org/10.29408/jit.v4i1.2995

menguntungkan. Keberhasilan hubungan tersebut sangat bergantung kepada kepatuhan dua belah pihak dalam menjalankan perjanjian. Mitra juga diartikan sebagai teman, rekan kerja dan sebagainya yang saling menjalin kerjasama[11]. Mitra merupakan faktor penting dalam dunia bisnis. Bahkan, di kondisi tertentu, adanya mitra bisnis justru bisa membawa angin segar yang dapat menyelamatkan kondisi bisnis.

\section{CV. Rinjani Tirta}

Perusahaan ini didirikan pada tahun 2019 yang bergerak diibidang produk herbal yang memiliki 86 lebih produk yang terbuat dari herbal.CV. Rinjani Tirta merupakan salah satu perusahaan yang mendapat izin BPOM di lombok timur dan sudah masuk 96 perusahaan yang direkomendasikan oleh BPOM untuk tetap mengikuti kegiatan yang diadakan oleh BPOM maupun pemerintah yang berkaitan dengan izin, seminar, dan pameran produk.

4. GIS (Geographic Information System)

GIS (Geographic information system) atau SIG (Sistem informasi geografis) mulai dikenal pada awal 1980-an. SIG dapat diartikan sebagai suatu komponen yang terdiri dari perangkat keras, perangkat lunak, data geografis dan sumberdaya manusia yang bekerja bersama secara efektif untuk menangkap, menyimpan, memperbaiki, memperbaharui, mengelola, memanipulasi, mengintegrasikan, menganalisa, dan menampilkan data dalam suatu informasi berbasis geografis. Informasi spasial memakai lokasi, dalam suatu sistem koordinat tertentu, sebagai dasar referensinya. Karenanya SIG mempunyai kemampuan untuk menghubungkan berbagai data pada suatu titik tertentu di bumi, menggabungkannya, menganalisa dan akhirnya memetakan hasilnya. Aplikasi SIG menjawab beberapa pertanyaan seperti: lokasi, kondisi, trend, pola, dan pemodelan. Kemampuan inilah yang membedakan SIG dari sistem informasi lainnya. Dilihat dari definisinya, SIG adalah suatu sistem yang terdiri dari berbagai komponen yang tidak dapat berdiri sendirisendiri. GIS juga sudah terintegrasi dengan google maps ataupun penyedia data spasial yang sudah cukup terkenal[7], [12].

\section{Google API}

Google menyediakan berbagai API (Application Programming Interface) yang sangat berguna bagi pengembangan web maupun aplikasi desktop untuk memanfaatkan berbagai fitur yang disediakan oleh google seperti misalnya : AdSense, Search Engine, Translation maupun YouTube. API secara sederhana bisa diartikan sebagai kode program yang merupakan penghubung antara web yang kita buat dengan fungsi yang dikerjakan. Misalnya dalam hal ini Google API berarti kode program (yang disederhanakan) yang dapat kita tambahkan pada web yang dibuat untuk mengakses, 
DOI : 10.29408/jit.v4i1.2995 Link : https://dx.doi.org/10.29408/jit.v4i1.2995

menjalankan, memanfaatkan fitur yang disediakan Google. Misalnya saja kita bisa menambahkan fitur Google Maps pada website kita untuk menghubungkan data spasial sebuah daerah bahkan menandainya[12].

\subsection{Tahapan Penelitian}

Pada gambar 1. Merupakan tahapan yang dilakukan penulis dalam penelitian yang teridiri dari:

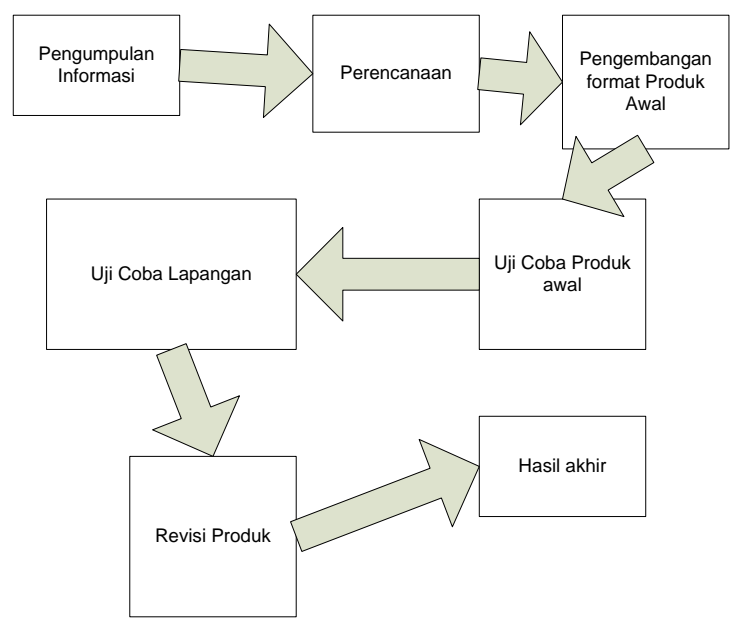

Gambar 1 Tahapan penelitian

1. Pengumpulan Informasi

Pada tahapan ini penulis mengumpulkan informasi tentang pendataan mitra CV.Rinjani Tirta.

2. Perencanaan

Perencanaan ini untuk menentukan bahan dan model awal produk yang akan dibuat.

3. Pengembangan Format Produk Awal Melakukan penyiapan bahan untuk membuat aplikasi pendataan mitra CV.Rinjani Tirta.
4. Uji Coba Produk Awal

Pada tahapan ini dilakukan uji coba pada aplikasi yang dikembangkan sebelum melakukan nya di lapangan.

5. Uji Coba Lapangan

Proses uji coba di lapangan apakah aplikasi yang dibuat sesuai dengan perencanaan atau tidak.

6. Revisi Produk

Pada tahapan ini dilakukan perbaikan pada aplikasi dan penyempurnaan sesuai dengan kondisi di lapangan setelah uji coba.

7. Hasil Akhir

Pada tahapan ini produk sudah bisa dioperasikan secara normal.

\section{Metode Penelitian}

\subsection{Metodologi dalam penelitian}

Peneliti menerapkan beberapa cara untuk mendapatkan data yang benar-benar bisa digunakan, akurat dan relevan terhadap hasilnya diantaranya adalah:

1. Observasi

Observasi merupakan kegiatan pengamatan langsung terhadap suatu pristiwa yang diikuti pencatatan secara urut untuk mengumpulkan data yang berhubungan dengan objek penelitian. Penelitian dilakukan di perusahaan CV. Rinjani Tirta. 
DOI : 10.29408/jit.v4i1.2995 Link : https://dx.doi.org/10.29408/jit.v4i1.2995

2. Interview

Interview merupakan teknik untuk melengkapi dan menambahkan data yang telah ada dan bertanya langsung pada sumber data yaitu pemilik perusahaan Andrie Mujiarto NP.

3. Studi Pustaka

Studi Pustaka adalah kegiatan untuk menghimpun informasi yang relevan dengan topik atau masalah yang menjadi objek penelitian. Informasi tersebut dapat diperoleh dari buku-buku, karya ilmiah, tesis, disertai, ensiklopedia, internet dan sumber-sumber lain. Adanya studi pustaka, peneliti dapat memanfaatkan semua informasi dan pemikiran-pemikiran yang relevan dengan penelitiannya.

\subsection{Lokasi Penelitian}

Penelitian ini dilakukan dengan mengumpulkan data yang diambil dengan cara menanyakan langsung pada Andrie Mujiarto NP selaku narasumber pemilik perusahaan CV.Rinjani Tirta yang berada di desa Ajani Timur kecamatan suralaga.

\subsection{Pengumpulan Bahan}

Dalam proses pembuatan SIG dari mitra CV.Rinjani Tirta dibutuhkan suatu perangkat keras dan perangkat lunak yaitu :

1. Perangkat Keras (Hardware)
Hardware merupakan suatu perangkat keras yang berfungsi dalam pembuatan Rekayasa perangkat lunak berbasis GIS.

Tabel 1: Perangkat yang dibutuhkan

No. Perangkat Keras (Hardware)

1. Laptop Asus A456U SonicMaster

2. Harddisk SSD 228gb

2. Perangkat Lunak

Perangkat lunak yang dibutuhkan yaitu :

Tabel 2: Perangkat lunak

\begin{tabular}{ll}
\hline No. & Perangkat Lunak \\
\hline 1. & Windows 10 \\
\hline 2. & XAMPP \\
\hline 3. & Visual Studio Code \\
\hline 4. & Browser
\end{tabular}

\section{Hasil dan Pembahasan}

Berikut adalah hasil dan pembahasan dari penelitian pendataan mitra CV.Rinjani Tirta berbasis GIS.

1. Tampilan Halaman Lokasi Mitra

Pada gambar 2. Merupakan Halaman untuk menampilkan semua lokasi mitra yang sudah diinput oleh admin beserta detail dan deskripsiya. Lokasi mitra ini dapat di lihat oleh user ketika mengakses website sehingga dapat dengan mudah mengetahui titik-titik lokasi mitra CV. Rinjani Tirta yang berada di Lombok Timur. 


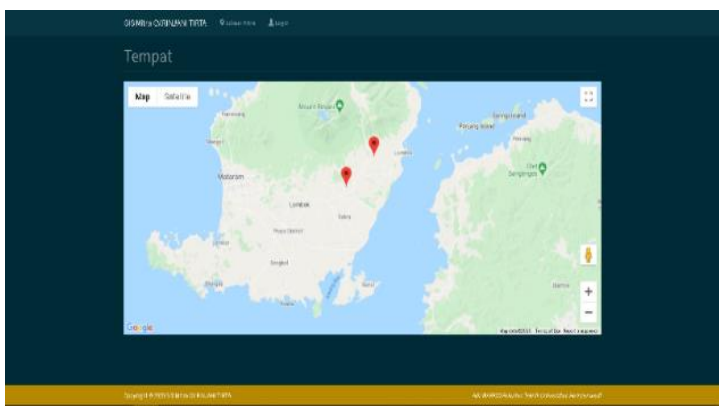

Gambar 2 Tampilan lokasi mitra

2. Tampilan Halaman Detail Rute Lokasi

Dapat terlihat pada gambar 3. Halaman ini menampilkan titik lokasi serta jarak dan rute menuju lokasi mitra yang ingin dituju yang sudah di input oleh admin sehingga dapat dilihat oleh user.

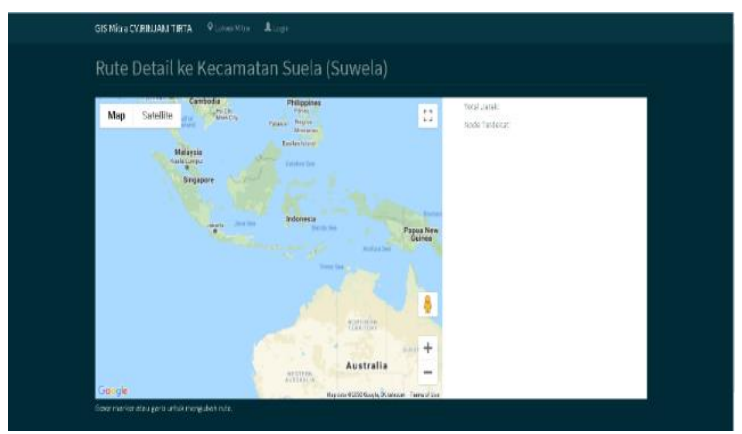

Gambar 3 Tampilan rute lokasi

3. Tampilan Lokasi Mitra Admin

Terdapat pada gambar 4. Halaman ini adalah halaman yang hanya bisa di akses oleh admin yang berfungsi untuk menambah, mengubah ataupun menghapus data lokasi mitra CV .Rinjani Tirta yang berada di Lombok timur dimana hasilnya nanti dapat di lihat oleh user.

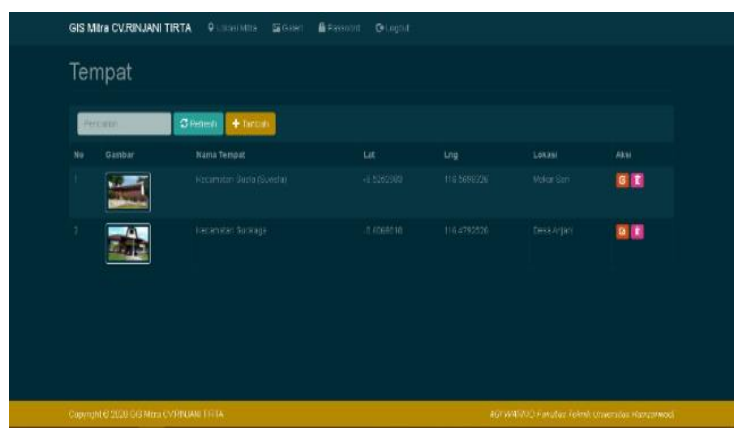

Gambar 4 Tampilan lokasi mitra admin

4. Tampilan Halaman Login Admin

Gambar 5. merupakan halaman untuk melakukan proses login. Halaman ini hanya bisa dikases oleh admin ketika ingin menambah dan merubah data mitra serta data lainya, dengan memasukan username dan password sesuai dengan data yang ada di database di sistem.

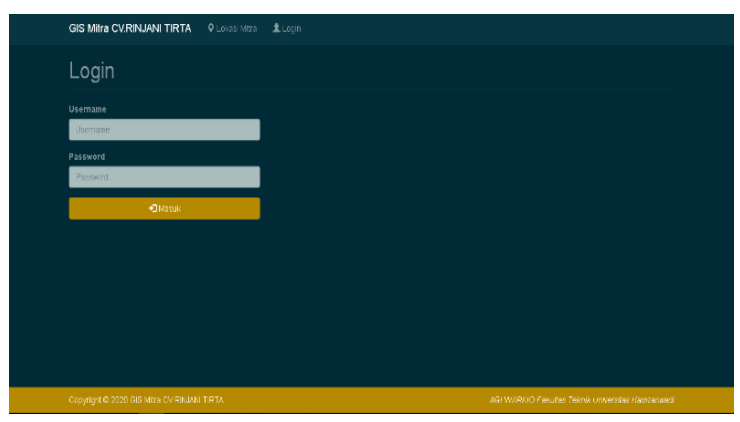

Gambar 5 Tampilan Login Admin

Pemetaan lokasi mitra CV. Rinjani Tirta yang tersebar di kabupaten lombok timur. Pemanfaatan perangkat lunak berbasis Geographic information system (GIS) ini dikembangkan dengan memanfaatkan Aplication Program Interface (API) milik google, dimana data yang dibutuhkan adalah titik koordinat dari lokasi mitra yang menjual produk 
DOI : 10.29408/jit.v4i1.2995 Link : https://dx.doi.org/10.29408/jit.v4i1.2995

herbal CV. Rinjani Tirta dengan mengambil data longtitude dan latitude dari setiap lokasi.

Adanya aplikasi ini mempermudah masyarakat secara luas dalam mencari lokasi keberadaan mitra khususnya kabupaten lombok timur yang dapat diakses dengan mudah dengan memanfaatkan internet.

\section{Kesimpulan}

Berdasarkan implementasi dan pembahasan yang telah dilakukan maka terdapat beberapa kesimpulan yang dapat diambil diantaranya adalah sebagai beikut :

1. SIG pendataan mitra ini akan sangat membantu CV.Rinjani Tirta dalam promosi serta pengumpulan informasi mengenai mitra dan daerah yang sudah banyak tersebar produk dari CV.Rinjani Tirta.

2. Sekaligus menaikkan nilai dalam pandangan orang tentang perusahaan ini karena sudah punya data digital sendiri. Selain itu, untuk mengefektifkan kerja dari karyawan dan tentunya promosi dari mitra secara tidak langsung.

\section{Daftar Pustaka}

[1] Xin Zhang, Tianhe Chi, Huabin Chen, and Hongrui Zhao, "Research on Electronic Government oriented geographic information service system," in IGARSS 2003. 2003 IEEE International Geoscience and Remote Sensing Symposium. Proceedings (IEEE Cat. No.03CH37477), vol. 6, pp. 3796-3798, doi: 10.1109/IGARSS.2003.1295273.

[2] I. Fathurrahman and M. Saiful, "Implementasi Web Service Dalam Pengembangan Sistem Informasi Desa Berbasis Android Pada Desa Darmasari Kecamatan Sikur Kabupaten Lombok Timur," Infotek J. Inform. dan Teknol., vol. 2, no. 2, pp. 135-142, Aug. 2019, doi: 10.29408/jit.v2i2.1459.

[3] A. Muliawan Nur and M. Mahfuz, "Pemetaan Rumah Makan Lesehan Di Kecamatan Selong Dan Masbagik Kabupaten Lombok Timur Berbasis Gis (Geographic Information System)," Infotek J. Inform. dan Teknol., vol. 3, no. 1, pp. 814, Feb. 2020, doi: 10.29408/jit.v3i1.1803.

[4] A. Sudianto, N. Nurhidayati, and L. Kerta Wijaya, "Penerapan Sistem Informasi Geografis Untuk Pemetaan Bengkel Tambal Ban di Kecamatan Selong Kabupaten Lombok Timur," Infotek J. Inform. dan Teknol., vol. 3, no. 1, pp. 5157, Feb. 2020, doi: 10.29408/jit.v3i1.1824.

[5] R. Setiawan, D. Kurniadi, and $H$. Bunyamin, "Perancangan Sistem Pengelolaan Penanggulangan Bencana Alam Garut Berbasis Sistem Informasi Geografis," J. Algoritm., vol. 14, no. 2, pp. 
DOI : 10.29408/jit.v4i1.2995 Link : https://dx.doi.org/10.29408/jit.v4i1.2995

343-349, Feb. 2015, doi: Kerajinan di Kabupaten Lombok Timur," 10.33364/algoritma/v.14-2.343.

[6] M. Yanto, "Sistem Informasi Geografis Infotek J. Inform. dan Teknol., vol. 1, no. 2, Lokasi Perkebunan Disepanjang Garis pp. 71-78, Jul. 2018, doi: Pantai Pesisir Selatan Berbasis Android," J. Ilm. Media Sisfo, vol. 13, no. 1, p. 28, Apr. 2019, doi: 10.33998/mediasisfo.2019.13.1.586.

[7] O. Nurdiawan, H. Putri, P. Studi, and T. Informasi, "Pemetaan daerah rawan banjir berbasis sistem informasi geografis dalam upaya mengoptimalkan langkah antisipasi bencana," J. Infotech, vol. 4, no. 2, pp. 1-9, 2014.

[8] A. Sudianto and M. Sadali, "Penerapan Sistem Informasi Geografis (GIS) dalam 10.29408/jit.v1i2.882.

[9] Soekidjo, Pengembangan Potensi Wilayah. Gramedia, 1994.

[10] Juhadi dan Dewi Liesnoor Setiyowati, Desain dan Komposisi Peta Tematikitle. Semarang: Geografi UNNES., 2001.

[11] A. T. Sulistiyani, Kemitraan dan modelmodel pemberdayaan. Gava Media, 2004.

[12] Muliyadi, D. B. Rendra, and F. Darma, "Aplikasi Pendataan Menara Telekomunikasi Berbasis Gis Di Kota Serang," J. PROSISKO, vol. 2, no. 2, pp. 69-73, 2015.

Pemetaan Kerajinan Kain Tenun dan Gerabah untuk Meningkatkan Potensi 